Journal of Educational Research in Developing Areas (JEREDA)

Vol. 2. Issue 1, Pp. 63-75, 2021

http://www.jeredajournal.com

E-mail: info@jeredajournal.com

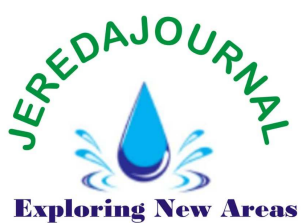

Research Article DOI: https://doi.org/10.47434/JEREDA.

eISSN: $2735-9107$

\title{
WORKING CONDITIONS ON RETENTION OF SCIENCE TEACHERS IN PUBLIC SECONDARY SCHOOLS IN KISUMU COUNTY, KENYA
}

\section{$*^{1}$ Edwin Otieno Obungu, ${ }^{2}$ Felicita Wanjiru Njuguna, ${ }^{3}$ Florence Muthoni Itegi}

\author{
${ }^{1,2,3}$ Department of Educational Management, Policy and Curiculum Studies, Kenyatta, Kenya \\ ${ }^{1}$ edu.mcobungu@gmail.com, ${ }^{2}$ njuguna.felicita@ku.ac.ke, ${ }^{3}$ itegi.florence@ku.ac.ke \\ *Corresponding author: ${ }^{1}$ edu.mcobungu@gmail.com
}

(iD) https://orcid.org/0000-0001-6175-3696

Received: $7^{\text {th }}$ April, 2021; Revised: $16^{\text {th }}$ April, 2021; Accepted: $29^{\text {th }}$ April, 2021

\begin{abstract}
Introduction: Low retention of science teachers has become a major problem in the education sector all over the world.

Purpose: The study investigated the effect of working conditions on retention of science teachers in public secondary schools in Kisumu County, Kenya.

Methodology: Embedded mixed method design was adopted for the study while target population included 905 respondents which comprised 221 principals and 684 science teachers from 221 public secondary schools in Kisumu County. Stratified, simple random and purposive sampling techniques were employed to sample 277 respondents who included 68 principals and 209 science teachers. Science teachers questionnaires and principals interview schedule were used to collect data. Pilot study was conducted in 7 public secondary schools in Kisumu County. Validity of the data collection instruments was determined through expert judgment whereas reliability was ascertained through internal consistency method using Cronbach's Alpha coefficient formula which yielded 0.848. Statistical Package for Social Sciences version 22.0 facilitated analysis of quantitative data. Quantitative data was analyzed using descriptive and inferential statistics while thematic approach was used to analyze qualitative data. Quantitative findings were presented in tables whereas qualitative data were presented in narratives and verbatim form according to themes.

Results: The study established that working conditions significantly affected retention of science teachers and this included factors such as employee representation, health and safety and working load.

Recommendations/Classroom Implications: Principals should make a deliberate effort to provide protective clothes, warning signs and laboratory equipment to protect users from harmful emissions.
\end{abstract}

Keywords: Working conditions, science teachers, retention, secondary school, working load, health and safety

\section{Cite paper as:}

Crossref Obungu, E. O., Njuguna, F. W., \& Itegi, F. M. (2021). Working conditions on Cited-by retention of science teachers in public secondary schools in Kisumu county, Kenya. Journal of Educational Research in Developing Areas, 2 (1), 63-75. https://doi.org/10.47434/JEREDA.2.1.2021.63

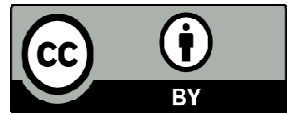

Copyright (c) 2021 The author(s) of this article retain(s) the copyright. 
Journal of Educational Research in Developing Areas (JEREDA)

Vol. 2. Issue 1, Pp. 63-75, 2021

http://www.jeredajournal.com

E-mail: info@jeredajournal.com

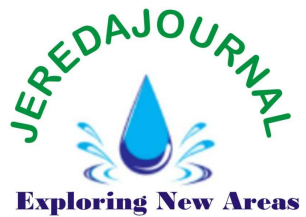

\section{PUBLIC INTEREST STATEMENT}

Retention of science teachers is critical to ensure uninterrupted flow of learning of science subjects in schools. This study therefore is significant to education stakeholders and policy makers in the Ministry of Education as it will help them to identify specific working conditions that affect retention of science teachers.

\section{INTRODUCTION}

Working conditions according to European Commission (2014) refer to working time, health and safety at work, work organization, employee representation and relation with the coworkers and employer in the work place. Similarly, retention means willingness including preparedness of science teachers to remain in teaching profession in public secondary schools until retirement. Science teachers in this study refer to professions specifically trained to teach Biology, Chemistry and Physics in public secondary schools. Working conditions are among the major factors that determine retention of science teachers in schools (Simon \& Johnson, 2015). Working conditions comprise a multiplicity of factors that influence teachers' overall day-to-day responsibilities and can range from physical materials, condition of facilities and equipment to behaviour of students, collegiality of coworkers and support from supervisors (European Union, 2013). In the present study, working conditions were operationalized to include working time, health and safety, work organization, representation and relation with the employer. Working conditions entail elements within the workplace environment that attract and retain talented employees. Basically, science teachers working conditions may have implications on their retention and provision of quality education.

Various studies indicate that employees working conditions relate positively to their retention (Ojaka, Olango \& Jarris, 2014). A study conducted by Geiger and Pivovarova (2018) in Arizona, USA adopted a mixed method approach to examine the effects of working conditions on retention of teachers. The study found that schools where teachers rated their working conditions as more satisfactory had higher retention rates. Findings revealed that school facilities and resources, relations with administrators and colleagues, working time and representation in decision making affected retention of teachers. Even though the reviewed study adopted a mixed method approach, there were no findings regarding the effect of working conditions on retention of teachers. The study restricted its analysis to school level comparison between the groups because the sample of individual teachers was not sufficient to precisely estimate the relationship between perceived working conditions and teacher retention. Further, the study was conducted in a developed country and therefore, the results cannot be generalized in Kenya which is a developing country. The present study used inferential statistics to establish the effect of working conditions on retention of science teachers and also produce a Kenyan perspective.

Marinnete (2017) undertook a study in South West Region of Cameroon to examine the relationship between working conditions and attrition of teachers in secondary schools. From a target population of 5250 teachers in Fako, Meme and Ndian divisions, a sample of 370 teachers was selected through a simple random sampling technique to participate in the study. The findings of the study revealed that school environment was not conducive enough for teaching and learning, schools did not have sufficient teaching resources and the workload of teachers was unmanageable. Further, the findings revealed an inverse strong significant relationship between teachers working conditions and their retention. The use of descriptive and inferential statistics was suitable for establishing the relationship between working conditions and attrition of teachers. However, a study sample of 370 respondents representing $7 \%$ of the population was not representative enough to allow generalization of results to the 
Journal of Educational Research in Developing Areas (JEREDA)

Vol. 2. Issue 1, Pp. 63-75, 2021

http://www.jeredajournal.com

E-mail: info@jeredajournal.com

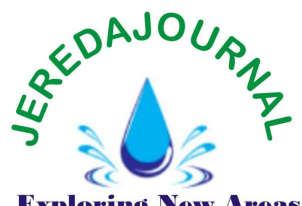

Exploring New Areas

entire population. Therefore, the present study used Slovin's formulae of sample size determination and determined a representative sample size for generalization of findings.

In Rwanda, Gatsinzi, Jesse and Makewa (2014) employed a correlational research design to examine the effect of work and school-related variables on teacher motivation. The key findings of the study revealed that workload, nature of work and school facilities significantly correlated with teacher motivation. While the reviewed study showed the relationship between working conditions and teacher motivation, the study was conducted among primary school teachers and the findings may not apply to secondary school teachers. Therefore, the study measured the effect of working conditions on retention of science teachers in secondary schools.

A study conducted by Joram, Wanjala and Matula (2018) examined the influence of institutional factors on job commitment among teachers in primary schools in Kenya. Descriptive survey design was adopted with a population of 63 Headteachers and 315 teachers. A random sample of 17 schools with 17 Headteachers and 95 teachers were selected for the study. The findings of the study were that majority of the teachers $(80 \%)$ were not involved in important decision-making processes in their schools which was considered as one of the major factors reducing their commitment in the teaching profession. A sample of 17 Headteachers and 95 teachers out of a population of 63 Head Teachers and 315 teachers was representative enough to allow generalization of results to the rest of the population. However, the study basically adopted a quantitative approach and there were no qualitative aspects regarding the teachers' desire to continue in the profession. Furthermore, the study was done among primary school teachers and hence the findings cannot be generalized to science teachers in secondary schools. The current study adopted a mixed method approach and included qualitative aspects and was conducted among science teachers in secondary schools in Kisumu County.
Odukah (2016) adopted a descriptive survey research design to investigate factors influencing staff motivation among employees in Kisumu County. The study aimed at establishing the relationship between working conditions and motivation of staff. A self constructed questionnaire was used to collect data whereas analysis of data was done in percentages and frequencies. The findings of the study revealed that flexible working hours, facilities and support from colleagues affected employee motivation. Even though the reviewed study examined variables related to working conditions, the study mainly related the variables to employee motivation. In fact, descriptive statistics such as frequencies and percentages cannot indicate the relationship between working conditions and employee motivation. The present study therefore employed inferential statistics and established the effect of working conditions on retention of science teachers in public secondary schools in Kisumu County.

\section{STATEMENT OF THE PROBLEM}

Teachers Service Commission (TSC) initiated a revised scheme of service for graduate teachers as a strategy to improve the working conditions in 2007 to attract, motivate, and facilitate retention of suitably qualified teachers in the teaching profession. Despite the implementation of this initiative in 2007, average teacher shortage still stands at 116,513 in 2018 and teachers are quitting the teaching profession at a higher rate especially science teachers. This acute teacher shortage caused by high turnover is a threat to the provision of quality education especially in science subjects.

Records show that the rate of science teachers' turnover is higher than that of the national government in Kisumu County, TSC unit. Besides, Kisumu County is among the top five counties leading in teacher shortage despite its city status. Therefore the researchers examined the effect of working conditions on retention of science teachers in public secondary schools in Kisumu County, Kenya. 
Journal of Educational Research in Developing Areas (JEREDA)

Vol. 2. Issue 1, Pp. 63-75, 2021

http://www.jeredajournal.com

E-mail: info@jeredajournal.com

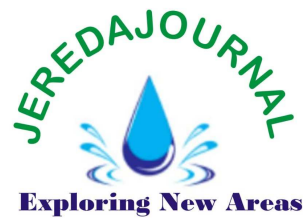

\section{PURPOSE OF THE STUDY}

1. Investigate the effect of working conditions on retention of science teachers in public secondary schools in Kisumu County, Kenya.

2. Establish the mean responses of Science teachers to effect of working conditions on retention in public secondary schools.

\section{RESEARCH QUESTIONS}

1. What is the effect of working conditions on retention of science teachers in public secondary schools in Kisumu County, Kenya?

2. What are the mean responses of Science teachers to effect of working conditions on retention in public secondary schools?

\section{HYPOTHESIS}

1. There is no statistically significant relationship between working conditions and retention of science teachers in public secondary schools in Kisumu County, Kenya.

\section{METHODOLOGY \\ Research Design}

The study adopted embedded design which is one of the six variants of mixed methods research designs (Ivankova \& Stick, 2007; Creswell \& Clark, 2011; Creswell, 2012). Embedded design allowed the researcher to collect and analyze both quantitative and qualitative data (Creswell \& Clark, 2011).

\section{Population and Sample}

The target population of this study included all the principals and science teachers in the 221 public secondary schools in Kisumu County. Thus, the study targeted a total of 905 respondents comprising 221 principals and 684 science teachers. Table 1 shows the distribution of target population of principals and science teachers as per category of schools in Kisumu County.

Table 1: The distribution of target population of principals and science teachers

\begin{tabular}{|c|c|c|c|c|c|}
\hline $\begin{array}{l}\text { School } \\
\text { Category }\end{array}$ & $\begin{array}{l}\text { No.of } \\
\text { Schools }\end{array}$ & $\begin{array}{l}\text { No.of } \\
\text { Principals }\end{array}$ & $\begin{array}{l}\text { No.of } \\
\text { Teachers }\end{array}$ & Science & TOTAL \\
\hline Boys & 17 & 17 & 47 & & 64 \\
\hline Girls & 25 & 25 & 89 & & 114 \\
\hline Mixed & 179 & 179 & 548 & & 727 \\
\hline TOTAL & 221 & 221 & 684 & & 905 \\
\hline
\end{tabular}

Source: Ministry of Education, 2018

Table 1 shows the total target population of 905 participants for the study. This comprised of 684 science teachers and 221 principals from three categories of schools namely, boys, girls and mixed schools in Kisumu County. Stratified, simple random and purposive sampling techniques were used to select 277 respondents for the study. Stratified sampling technique was used to categorize schools into 3 strata whereas simple random sampling technique was employed to select science teachers from each stratum. Simple random sampling enabled the researcher to ensure that each of the respondents had an equal chance of being involved in the study (Orodho, 2017). Purposive sampling technique was used to select principals. Sample size for both principals and science teachers was determined using Slovin's fomula.

\section{Instrument for Data Collection}

Questionnaires were used as the main instrument to collect quantitative data whereas qualitative data was collected through interview schedules. The items in the questionnaire were based on a 5 point 
Journal of Educational Research in Developing Areas (JEREDA)

Vol. 2. Issue 1, Pp. 63-75, 2021

http://www.jeredajournal.com

E-mail: info@jeredajournal.com

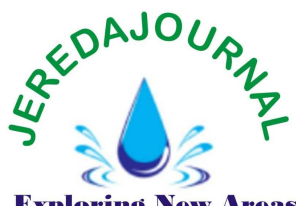

Likert scale with scores ranging from Strongly Disagree with a score of 1 ; Disagree, with a score of 2; Neutral with a score of 3; Agree with a score of 4 and Strongly Agree with a score of 5. Qualitative data were sought from the principals to complement the quantitative data obtained from science teachers. The purpose of interview in this study was to provide depth and details to the more general viewpoint offered by quantitative data (Edwards \& Holland, 2013).

Science teachers' questionnaire was subjected to content and face validity by two content experts' in education management, Kenyatta University. The experts' opinions were incorporated to the final draft for the study. Internal consistency method was adopted to establish the reliability coefficient. Accordingly, a Cronbach's alpha coefficient of 0.754 was realized indicating that the instrument was reliable.

\section{Procedure of Data Analysis}

The researcher sought for an introductory letter from the Dean, Graduate School, Kenyatta University to aid in application for research permit from the National Commission for Science, Technology and Innovation (NACOSTI), Ministry of Education. The researcher reported to the Kisumu County Commissioner, TSC Director, Kisumu County and the Director of Education, Kisumu County to seek permission to access and obtain data from the schools. The selected participants were then given consent forms to sign as an evidence of voluntary participation in the study. The research assistants thereafter administered the questionnaires to the selected respondents. The questionnaires were picked after two days to allow respondents adequate time to give well-informed opinions regarding the variables under study. On the day of picking the questionnaires, the researcher had an interview session with the principals to obtain qualitative data using the interview

schedule. The researcher asked for consent from the interviewee to allow recording of the interview using a tape recorder to avoid bias. Quantitative data were entered, cleaned and organized using the Statistical Package for Social Sciences (SPSS) version 22.0 software.

The descriptive statistics mainly frequencies, percentages, means and standard deviations were used to analyze the Likert scale data whereas Standard Multiple Regression analysis was used to test hypotheses and establish the effect of working conditions on retention. According to Keller (2014), the multiple regression formula is $y=a+\beta_{1 \times 1}+\beta_{2 \times 2}+\beta_{3 \times 3}+$ e. where $y$ represents the expected value of the dependent variable, a represents the expected value of the dependent variable if $\mathrm{x}_{1}, \mathrm{x}_{2}$ and $\mathrm{x}_{3}$ are all zero. Where $\mathrm{x}_{1}, \mathrm{x}_{2}$ and $\mathrm{x}_{3}$ are first, second and third predictor variables respectively. $\beta_{1}$ refers to the change in $y$ for each unit change in $x_{1}$ while holding $x_{2}$ and $x_{3}$ constant. $\beta_{2}$ refers to the change in $y$ for each unit change in $x_{2}$ while holding $x_{1}$ and $x_{3}$ constant and $\beta_{3}$ refers to change in $y$ for each unit change in $x_{3}$ while holding $x_{1}$ and $x_{2}$ constant. The " $e$ " refers to the error term, which stands for other variables that affect retention of science teachers but not considered in the present study. Qualitative data were summarized into themes. Techniques including interpretive and coding were used to summarize the datasets. Whereas interpretive method was used to give and report the researcher's impression in a structured form, coding was employed to organize the data and provided a way of introducing interpretations into quantitative findings.

\section{RESULTS}

Research Question 1: What are the mean responses of Science teachers to effect of working conditions on retention in public secondary schools?

The study sought to find the mean responses of effect of working conditions on retention of science teachers in Kisumu 
Journal of Educational Research in Developing Areas (JEREDA)

Vol. 2. Issue 1, Pp. 63-75, 2021

http://www.jeredajournal.com

E-mail: info@jeredajournal.com

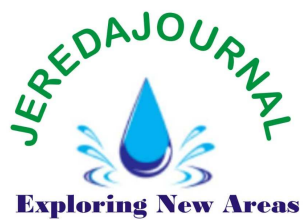

County. The findings are presented in Table

2.

Table 2: Science teachers' responses to effect of working conditions on retention in public secondary schools

\begin{tabular}{lllllllllllll}
\hline Statement & \multicolumn{3}{c}{ SD } & D & & U & & A & & SA & \multicolumn{3}{c}{$\begin{array}{l}\text { Mea } \\
\text { n }\end{array}$} & $\begin{array}{l}\text { Std. } \\
\text { Dev. }\end{array}$ \\
\cline { 2 - 13 } & $\mathrm{N}$ & $\%$ & $\mathrm{~N}$ & $\%$ & $\mathrm{~N}$ & $\%$ & $\mathrm{~N}$ & $\%$ & $\mathrm{~N}$ & $\%$ & & \\
\hline Lessons allocated & 43 & 21.6 & 55 & 27.6 & 5 & 2.5 & 63 & 31.7 & 33 & 16.6 & 2.94 & 1.46 \\
Number of students & 20 & 10.1 & 49 & 24.6 & 3 & 1.5 & 72 & 36.2 & 55 & 27.6 & 3.47 & 1.38 \\
Science laboratory & 43 & 21.6 & 63 & 31.7 & 10 & 5 & 68 & 34.2 & 15 & 7.5 & 2.74 & 1.33 \\
Textbooks & 10 & 5 & 35 & 17.6 & 4 & 2 & 106 & 53.3 & 44 & 22.1 & 3.70 & 1.15 \\
Adequate time & 28 & 14.1 & 63 & 31.7 & 6 & 3 & 85 & 42.7 & 17 & 8.5 & 3.00 & 1.29 \\
Instructional materials & 40 & 20.1 & 87 & 43.7 & 15 & 7.5 & 44 & 22.1 & 13 & 6.5 & 2.51 & 1.22 \\
Clean environment & 16 & 8 & 35 & 17.6 & 15 & 7.5 & 95 & 47.7 & 38 & 19.1 & 3.52 & 1.21 \\
Amount of work & 27 & 13.6 & 75 & 37.7 & 13 & 6.5 & 49 & 24.6 & 35 & 17.6 & 2.95 & 1.37 \\
Laboratory & 61 & 30.7 & 82 & 41.2 & 11 & 5.5 & 33 & 16.6 & 12 & 6 & 2.26 & 1.23 \\
equipment & & & & & & & & & & & & \\
Well behaved students & 23 & 11.6 & 37 & 18.6 & 21 & 10.6 & 110 & 55.3 & 8 & 4 & 3.22 & 1.15 \\
Health hazards & 26 & 13.1 & 60 & 30.2 & 24 & 12.1 & 75 & 37.7 & 14 & 7 & 2.95 & 1.22 \\
Warning signs & 51 & 25.6 & 79 & 39.7 & 17 & 8.5 & 44 & 22.1 & 8 & 4 & 2.39 & 1.20 \\
Health \& safety & 31 & 15.6 & 60 & 30.2 & 24 & 12.1 & 75 & 37.7 & 9 & 4.5 & 2.85 & 1.21 \\
Protective clothes & 67 & 33.7 & 58 & 29.1 & 13 & 6.5 & 57 & 28.6 & 4 & 2 & 2.36 & 1.27 \\
Opinion is considered & 18 & 9 & 35 & 17.6 & 23 & 11.6 & 99 & 49.7 & 24 & 12.1 & 3.38 & 1.17 \\
School committees & 17 & 8.5 & 40 & 20.1 & 17 & 8.5 & 100 & 50.3 & 25 & 12.6 & 3.38 & 1.19 \\
\hline
\end{tabular}

From Table 2, the findings indicate almost one half $(49.2 \%)$ of the science teachers disagreed that they were satisfied with number of lessons allocated to them while a significant number $(48.3 \%)$ agreed with the statement. The mean rating for this item was 2.94 and a standard deviation of 1.46 meaning that majority of science teachers in public secondary schools in Kisumu County are not satisfied with the number of lessons allocated to them implying that lessons allocated to science teachers might lead to their low retention. The descriptive findings also show that more than two thirds $(63.8 \%)$ of the respondents agreed that the number of students in classes they taught were high whereas 34.7 per cent disagreed with the statement. The statement had a mean rating and a standard deviation of 3.47 and
1.38 respectively showing that a large number of science teachers in Kisumu County handle high number of students in classes they teach. This implies that most science teachers are not satisfied with the high number of students which is overloading in their classes leading to low motivation and retention. Further, the findings show that majority $(53.3 \%)$ of the respondents disagreed that their schools had well equipped laboratories while 41.7 per cent agreed with the statement. The mean rating for this statement was 2.74 and standard deviation 1.33 implying that most schools in Kisumu County do not have well-equipped laboratories hence low retention of science teachers in such schools. The findings also show that more than two thirds $(62.8 \%)$ of the respondents disagreed that protective clothes were given 
Journal of Educational Research in Developing Areas (JEREDA)

Vol. 2. Issue 1, Pp. 63-75, 2021

http://www.jeredajournal.com

E-mail: info@jeredajournal.com

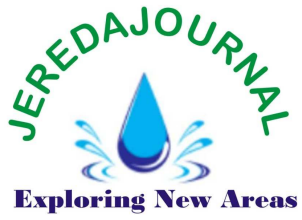

to science teachers while operating in the laboratories while only $30.6 \%$ agreed with the statement. The mean rating and standard deviation for the item 2.36 and 1.27 respectively, meaning that most science teachers in Kisumu County are not provided with protective clothes while operating in the laboratories. This implies that most science teachers in the county are dissatisfied with the non-provision of protective clothes while in the laboratories leading to low motivation and retention.

The findings in Table 2 further reveal that majority $(71.9 \%)$ of the respondents disagreed that laboratories in their schools had equipment to protect users from harmful emissions while only $22.6 \%$ agreed with the statement. The mean rating for this item was 2.26 and a standard deviation of 1.23. The study concludes that most laboratories in public secondary schools in Kisumu County do not have equipment to protect users from harmful emissions implying that science teachers are not motivated to teach in such schools. They prefer to join other schools or organizations if they get a chance hence low retention. The results also reveal that majority $(63.8 \%)$ of the respondents disagreed that their schools had enough instructional materials for science apart from textbooks whereas only $28.6 \%$ agreed with the statement. The mean rating for this item was 2.51 and a standard deviation of 1.22 implying that most science teachers in Kisumu County are not satisfied with the adequacy of instructional materials apart from textbooks for science subjects leading to low motivation and retention. The findings show that less than half $(44.7 \%)$ of the respondents agreed that their schools were free from health hazards whereas a significant number $(43.3 \%)$ disagreed with the statement. The mean rating and standard deviation for this item was 2.95 and 1.22 respectively implying that majority of science teachers in public secondary schools in Kisumu County are happy that their schools are free from health hazards. The findings imply that health hazards might not be an issue for low retention of

science teachers in the county. However, a sizeable number (43.3\%) of science teachers were dissatisfied that health hazards were still present in their schools meaning that health hazards is still an issue to a significant number of science teachers leading to low retention.

The findings also reveal that majority $(66.8 \%)$ of the respondents agreed that their school environments were clean and well-maintained whereas $25.6 \%$ disagreed with the statement. The item had a mean rating of 3.52 and a standard deviation of 1.21 meaning that most science teachers in public secondary schools in Kisumu County are satisfied with their school environments implying that clean and well maintained school environment might not be an issue for low retention. According to the results displayed in Table 2, more than half $(59.3 \%)$ of the respondents agreed that the students they teach are well-behaved whereas slightly more than one third $(30.2 \%)$ disagreed with the statement. The item had a mean rating of 3.22 and a standard deviation of 1.15 . The study concluded that most science teachers in public secondary schools in Kisumu County are satisfied with the behaviour of the students they teach and therefore, students' behavior might not be an issue for low retention.

Hypothesis 1: There is no statistically significant relationship between working conditions and retention of science teachers in public secondary schools in Kisumu County, Kenya

The hypothesis was formulated to establish the effect of working conditions on retention of science teachers in this study. In an attempt to test the hypothesis, data on working conditions and retention were collected from science teachers questionnaire. Retention was deduced from the composite score of all responses related to retention of science teachers in public secondary schools in Kisumu County. Multiple regression analysis was used to test the hypothesis. Tables 3 to 5 present data from regression analysis. 
Journal of Educational Research in Developing Areas (JEREDA)

Vol. 2. Issue 1, Pp. 63-75, 2021

http://www.jeredajournal.com

E-mail: info@jeredajournal.com

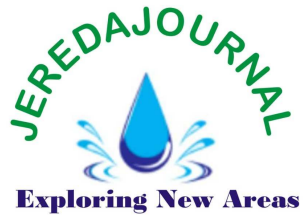

Table 3: Model summary of regression statistics on working conditions and retention of science teachers

\begin{tabular}{lllll}
\hline Model & R & $\begin{array}{l}\text { R } \\
\text { Squar } \\
\mathbf{e}\end{array}$ & $\begin{array}{l}\text { Adjusted } \\
\text { R Square }\end{array}$ & $\begin{array}{l}\text { Std. Error } \\
\text { of } \\
\text { Estimate }\end{array}$ \\
\hline 1 & .278 & .077 & .063 & .63205 \\
\hline $\begin{array}{l}\text { Predictors: (Constant), Workload (WL), Health and } \\
\text { Safety(HS), Employee Representation(ER) }\end{array}$
\end{tabular}

The findings in Table 3 show that correlation coefficient $(r=.28)$ for the regression analysis. This represents a weak relationship between working conditions and retention of science teachers in public secondary schools in Kisumu County. This is in line with Saunders (2000) who asserts that when $r=1$, this depicts a perfect linear correlation whereas when the value of $r$ is below 0.5 , then there is a weak correlation between the variables and finally, a negative $r$ shows negative relationship while zero depicts that there is no relationship between the variables.

Table 3 also presents the coefficient of determination which is given by Rsquare of .077 that showed how much the variation in retention of science teachers in Kisumu County was explained by working conditions. R- Square of .077 implies that $7.7 \%$ of variation in retention of science teachers in Kisumu County is explained by working conditions, namely; work load (WL), health and safety (HS) and employee representation (ER). Further, the findings also imply that $92.3 \%$ of variation in retention of science teachers in Kisumu County can be attributed to other factors. However, the coefficient of determination gives the overall measure of the strength of association between working conditions (WL, HS and ER) and retention (R) of science teachers which does not indicate the extent to which each independent variable, namely ( $W L, H S$ and $E R$ ) contributes to the dependent variable (R). It is therefore important to determine the regression weight (Beta) of each of the independent predictors. The findings are contained in Table 4.

Table 4: Regression co-efficient for the effect of working conditions on retention of science teachers

\begin{tabular}{|c|c|c|c|c|c|c|}
\hline \multirow{2}{*}{\multicolumn{2}{|c|}{$\begin{array}{l}\text { Coefficients }{ }^{a} \\
\text { Model }\end{array}$}} & \multicolumn{2}{|c|}{$\begin{array}{l}\text { Unstandardized } \\
\text { Coefficients }\end{array}$} & \multirow{2}{*}{$\begin{array}{l}\text { Standardized } \\
\text { Coefficients } \\
\text { Beta }\end{array}$} & \multirow{2}{*}{$\begin{array}{l}\mathbf{t} \\
14.216\end{array}$} & \multirow{2}{*}{$\begin{array}{l}\text { Sig. } \\
.000\end{array}$} \\
\hline & (Constant) & $\begin{array}{l}\text { B } \\
2.888\end{array}$ & $\begin{array}{l}\text { Std. Error } \\
.203\end{array}$ & & & \\
\hline & $\begin{array}{l}\text { Employee } \\
\text { Representation(ER) }\end{array}$ & .114 & .042 & .200 & 2.716 & .007 \\
\hline & $\begin{array}{l}\text { Health \& Safety (HS) } \\
\text { Workload (WL) }\end{array}$ & $\begin{array}{l}.096 \\
-.116\end{array}$ & $\begin{array}{l}.040 \\
.040\end{array}$ & $\begin{array}{l}.168 \\
-.216\end{array}$ & $\begin{array}{l}2.410 \\
-2.898\end{array}$ & $\begin{array}{l}.017 \\
.004\end{array}$ \\
\hline
\end{tabular}

a. Dependent Variable: RETENTION $\quad \mathrm{p}<.05$ 
Journal of Educational Research in Developing Areas (JEREDA)

Vol. 2. Issue 1, Pp. 63-75, 2021

http://www.jeredajournal.com

E-mail: info@jeredajournal.com

Table 4 shows the amount of change in retention of science teachers that can be predicted from one unit change in (WL, HS and $E R$ ). Data for the three indicators (WL, HS and ER) were generated by combining several items to represent each of the indicators. Further, Table 4 indicates that the "Constant" which indicates the predicted value of retention of science teachers when working conditions is zero is 2.888 . In terms of the independent predictors, the findings indicate that for ER, the Beta is .200 implying that for every unit increase in $E R$, a .200 unit increase is retention of science teachers is predicted. In addition, for every unit increase in HS, a .168 unit rise in retention of science teachers is predicted. The findings however show that for every unit increase in $W L, a-.216$ decrease in retention of science teachers is predicted. Findings further indicate whether each predictor variable is making a statistically significant contribution to the model at a significance level of $p<.05$.

Table 5: Analysis of variance for working conditions and retention of science teachers

\begin{tabular}{llllll} 
Model & $\begin{array}{l}\text { Sum of } \\
\text { Squares }\end{array}$ & Df & $\begin{array}{l}\text { Mean } \\
\text { Square }\end{array}$ & F & Sig. \\
\hline Regression & 6.510 & 3 & 2.170 & 5.432 & $.001^{\mathrm{b}}$ \\
Residual & 77.900 & 195 & .399 & & \\
Total & 84.410 & 198 & & & \\
\hline
\end{tabular}

a. Dependent Variable: RETENTION

b. Predictors: (Constant), Workload, Health and Safety, Employee

Representation

From the data presented in Table 5, it can be ascertained that the value of the calculated $F$ is 5.432 with 3 and 195 degrees of freedom and $F$ being significant at less than 0.05 . These findings indicate that the regression analysis appears to be appropriate since the significant value of $p$ $=0.001$ was statistically significant $(p<$ $0.05)$. Therefore the significant regression equation from the output could be stated as; $F(3,195)=5.432, p<0.05)$. Since the significant value of $p=0.001$ is less than $p$ value $(0.05)$, the null hypothesis is rejected. This implies that the alternative hypothesis which states that there is a statistically significant relationship between working conditions and retention of science teachers in public secondary schools in Kisumu County, Kenya was accepted.

\section{DISCUSSIONS}

The study revealed that science teachers were dissatisfied with certain 
Journal of Educational Research in Developing Areas (JEREDA)

Vol. 2. Issue 1, Pp. 63-75, 2021

http://www.jeredajournal.com

E-mail: info@jeredajournal.com

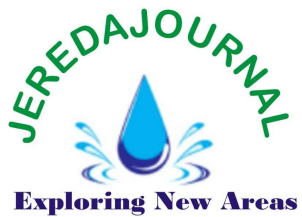

aspects of their working conditions. For example, the issue of high number of students in their classes, lack of laboratory equipment to protect them from harmful emissions and lack of protective clothes is a major concern for most science teachers. Consequently, the science teachers are demotivated and therefore would quit the profession in case an opportunity arises. This is in agreement with Ingersoll (2014) who reported that 45 per cent of teachers who quit teaching were dissatisfied with working conditions such as large class sizes, long working hours, inadequate classroom resources and lack of involvement in decision making. Similarly, Marinnete (2017) examined the relationship between working conditions and attrition of teachers in secondary schools in Cameroon and found that school environment was not conducive enough for teaching and learning, schools did not have sufficient teaching resources and the workload of teachers was unmanageable. The study concluded that there was an inverse strong relationship between teachers working conditions and their retention.

Further, the findings of the present study are in tandem with the findings of Gatsinzi, Jesse and Makewa (2014); Geiger and Pivovarova (2018); Marinnete (2017); Odukah (2016) and Sims (2017). For example, Geiger and Pivovarova (2018) in their study found that schools where teachers rated their working conditions as more satisfactory had higher retention rates. Findings also revealed that school facilities and resources, relations with administrators and colleagues, working time and representation in decision making affected retention of teachers.

The present study also established that improved employee representation, health and safety and reduced workload would lead to an increase in retention of science teachers in public secondary schools in Kisumu County. This is in agreement with Geiger and Pivovarova (2018) and Joram, Wanjala and Matula (2018) who found that teachers' representation and participation in

decision making affected their retention. Similarly, Sims (2017) established that teachers workload had a strong positive association with their retention. This implies that the alternative hypothesis which states that there is a statistically significant relationship between working conditions and retention of science teachers in public secondary schools in Kisumu County, Kenya was accepted. This is in agreement with Marinnete (2017) who reported that there was an inverse strong significant relationship between teachers working conditions and their retention.

The qualitative findings of the interview with the principals are in tandem with the findings recorded in Table 2 . Most of the principals felt that even though there were enough teaching and learning materials for science subjects, science teachers were dissatisfied with certain aspects of their working conditions. For example, the issue of high number of students in their classes, lack of laboratory equipment to protect them from harmful emissions and lack of protective clothes is a major concern for most science teachers. Consequently, the science teachers are demotivated and therefore would quit the profession in case an opportunity arises.

One of the principals reported:

The workload is too high for them because we have classes that are as large as 60 students, for example we have a Biology class with 69 students. Number of lessons increased due to the $100 \%$ transition policy by the government. It is not practical to teach 32 lessons in a week because there is the preparation bit of it so a teacher just makes a technical appearance because he/she is required to be in class. Anything above 20 lessons is not manageable.

Another principal described the working condition as pathetic owing to the workload and number of students in the classrooms. The principal stated: 


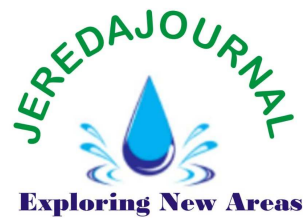

I would say it is pathetic because, the TSC, science teachers have a workload of over 30 lessons and that is why we have also employed B.O.M teachers, and when you look at science, they must have practical lessons and theory and all that. It is not easy, it is not possible for you to attend all those classes, some are double lessons, they are practical, you are preparing for other classes, you are resting for one hour and prepare for another class..... it is not possible. So I would describe it as pathetic.

The researchers observed that majority of the principals had positive responses regarding the status of the teaching and learning resources as reported by one some of the principals:

Now the status of learning materials is good since the government started supplying books to schools, like in text books, you find that our ratio has really improved. Virtually, I believe all students have textbooks in science areas and other reference books." Moreover, another principal had this to say: "I want to thank the government because I think when the government came up with the policy for direct supply of books to schools, so we have enough materials. However, the biggest challenge is now the vote head that we used to get on books we used to buy some of the equipment for the laboratory, now we have more textbooks but when it comes to the apparatus in the laboratories, now we don't have enough funding i.e the government does not supply apparatus.

\section{CONCLUSION}

Based on the findings that, employee representation, health and safety and work load had statistically significant effect on

retention of science teachers, it was logical to conclude that working conditions have statistically significant effect on retention of science teachers in public secondary schools in Kisumu County.

\section{RECOMMENDATIONS}

Based on the results and conclusions of the study, it was recommended that first, in order to improve the working conditions of science teachers, school principals should make a deliberate effort to provide protective clothes, warning signs and laboratory equipment to protect users from harmful emissions.

Second, based on the finding that science teachers had unmanageable workload, it was recommended that Teachers Service Commission should employ more science teachers to make their workload manageable.

Conflicts of Interest: The authors declare no conflict of interest.

Acknowledgments: The authors acknowledge the cooperation given by principals and science teachers of the selected public secondary schools during data collection period.

\section{Disclaimer Statement}

This work is part of a thesis submitted to Kenyatta University for the award of degree of Doctor of Philosophy $(\mathrm{PhD})$ in Educational Administration. Title of the thesis is "Effect of teachers' service commission motivational strategies on retention of science teachers in public secondary schools in Kisumu County, Kenya" The amount of work extracted from the thesis include, introduction, literature review, methodology, results, discussions and recommendations. Department of Education Management, Policy and Curriculum Studies, Kenyatta University; Names of supervisors: Dr. Florence Itegi and Dr. Felicita Njuguna. 
Journal of Educational Research in Developing Areas (JEREDA)

Vol. 2. Issue 1, Pp. 63-75, 2021

http://www.jeredajournal.com

E-mail: info@jeredajournal.com

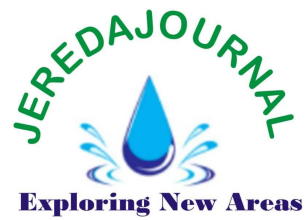

\section{Notes on Authors}

Edwin Obungu is a PhD student in the Department of Education Management, Policy and Curriculum Studies, School of Education, Kenyatta University, Kenya. He is currently a senior administrative assistant at Kenyatta University. His research interests are in the areas of leadership and human resource management in education and strategic management.

Felicita Njuguna is a senior lecturer in the department of education management, policy and curriculum studies, Kenyatta University. She holds a PhD in Education management. Her areas of research interest include leadership, education management and policy issues in education.

Florence Itegi is a senior lecturer in the department of education management, policy and curriculum studies, Kenyatta University. She holds a PhD in Education management. Her areas of research interest include leadership, education management and policy issues in education.

\section{Authorship and Level of Contribution} Edwin Otieno Obungu drafted the manuscript, collected, analyzed and interpreted data.

Felicita Njuguna validated the instruments and proofread the manuscript. Further, she assisted in the interpretation and discussion of results.

Florence Itegi formulated the items in the instruments and assisted in the interpretation and discussion of results.

\section{REFERENCES}

Creswell, J. (2012). Educational research: Planning, conducting and evaluating quantitative and qualitative research $\left(4^{\text {th }}\right.$ ed $) . \quad$ SAGE Publications.

Creswell, J., \& Clark, P. (2011). Designing and conducting mixed methods research $\left(2^{\text {nd }} \quad E d.\right)$. Sage.

Edwards, R., \& Holland, J. (2013). What is qualitative interviewing? $\left(1^{\text {st }}\right.$ ed). Bloomsbury.

European Union. (2013). Study on policy measures to improve the attractiveness of the teaching profession in Europe (Vol. 2). Author.

Gatsinzi, P., Jesse., R. \& Makewa, N. (2014). Work and school related variables in teacher motivation in gasabo district, Rwanda. Journal of Education and Training, 1(2), $262-275$.

Geiger, T., \& Pivovarova, M. (2018). The effects of working conditions on teacher retention. Teachers and Teaching: Theory and Practice, 122. https://doi.org/10.1080/13540602 .2018.1457524.

Ingersoll, R. (2014). Teacher turnover and teacher shortages: An organizational analysis. American Educational Research Journal, 38, 499-534.

Ivankova, N., \& Stick, S. (2007). Students persistence in a distributed doctoral programme in educational leadership in his/her education. A Mixed Methods Study. Research in Higher Education, 48 (1), 3-20.

Joram, L., Wanjala, G., \& Matula., P. (2018). Institutional factors influencing teachers' job commitment in public primary schools in Mwatate SubCounty, Kenya. International Journal of Education and Research, 6(4), 1-18.

Marinette, B. (2017). The impact of working conditions on teachers attrition in secondary schools in the south west region of Cameroon. International Journal of Education and Research, 5(6), 59-78.

Odukah, M. (2016). Factors influencing staff motivation among employees: Case of Equator Bottlers (Coca Cola) Kenya. Journal of Human Resource and Sustainability Studies, 4, 6879.

Ojakaa, D., Olango, S. \& Jarvis, J. (2014). Factors affecting motivation and 
Journal of Educational Research in Developing Areas (JEREDA)

Vol. 2. Issue 1, Pp. 63-75, 2021

http://www.jeredajournal.com

E-mail: info@jeredajournal.com

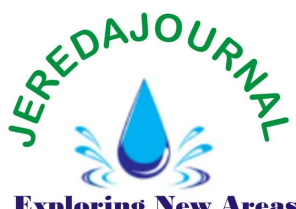

Exploring New Areas

retention of primary health care workers in three disparate regions in Kenya. Hum Resour Health, 12 (33), 4491-12-33.

https://doi.org/10.1186/1478-

Orodho, A. (2017). Techniques of writing research proposals and reports in education and social sciences: An illustrative guide to scholarly excellence. Kanezja Publishers and Enterprises.

Saunders, M. (2000). Research methods for business students ( $\left.2^{\text {nd }} e d\right)$. Pearson Education.

Simon, S., \& Johnson, M. (2015). Teacher turnover in high-poverty schools: What we know and can do. Teachers College Record, 117(3), 1-36.

Sims, S. (2017). Teaching and learning international survey 2013: Working conditions, teacher job satisfaction and retention. statistical working paper. Education Datalab. 